UDC 621.372

\title{
COUPLING COEFFICIENTS OF ROTATING RECTANGULAR DIELECTRIC RESONATORS WITH RECTANGULAR WAVEGUIDE
}

\author{
Alexander A. Trubin \\ Institute of Telecommunication Systems \\ Igor Sikorsky Kyiv Polytechnic Institute, Kyiv, Ukraine
}

Background. A further increase in the speed of information transfer is determined by more stringent requirements for the elements of communication devices. One of the most important components of such devices is various filters, which are often made on dielectric resonators. Calculation of the parameters of multi-section filters is impossible without further development of the theory of their design. The development of filter theory is based on electrodynamic modeling, which involves calculating the coupling coefficients of dielectric resonators in various transmission lines.

Objective. The aim of the research is to calculate and study the coupling coefficients of rectangular dielectric resonators with a rectangular metal waveguide when their axes rotate. Investigation of new effects to improve the performance of filters and other devices based on them.

Methods. Methods of technical electrodynamics are used to calculate and analyze the coupling coefficients. The end result is to obtain new analytical formulas for new structures with rectangular dielectric resonators, which make it possible to analyze and calculate their coupling coefficients.

Results. New analytical expressions are found for the coupling coefficients of dielectric resonators with the rotation of their axes in a rectangular waveguide.

Conclusions. The theory of designing filters based on new structures of dielectric resonators with rotation of their axes in metal waveguides has been expanded. New analytical relationships and new patterns of change in the coupling coefficients are found.

Keywords: dielectric filter; rectangular dielectric resonator; rotation; coupling coefficients.

\section{Introduction}

Band-pass and band-stop filters based on dielectric resonators of different shapes are used in access devices of various telecommunication systems [2-3]. Dielectric filter theory is well developed. Further improvement of filter characteristics can be achieved by using less traditional structures, in particular, dielectric resonators with rotation of their axes relative to each other and the transmission line $[1,3]$. To calculate and analyze the characteristics of such filters, it is required to calculate the coupling coefficients of the DR located at an arbitrary angle with respect to the waveguide axis.

\section{Statement of the problem}

Rectangular DRs are widely used in filter design [26]. The purpose of this article is to calculate and study the coupling coefficients of the rectangular DRs with the fundamental wave $H_{10}$ of a rectangular metal waveguide.

\section{Calculation of radiation fields during rotation of dielectric resonators in a waveguide.}

The field of natural oscillations $(\overrightarrow{\mathrm{e}}, \overrightarrow{\mathrm{h}})$ of a rectangular resonator with magnetic oscillations $\mathrm{H}_{\mathrm{nml}}$ in local DR coordinate system $\left(\mathrm{x}^{\prime}, \mathrm{y}^{\prime}, \mathrm{z}^{\prime}\right)$ (Fig.1, a) we represented in the form:

$$
\begin{gathered}
\mathrm{e}_{\mathrm{x}^{\prime}}=\frac{-\mathrm{h}_{1} \mathrm{i} \omega \mu_{0}}{\mathrm{k}_{1}^{2}-\beta_{\mathrm{z}}^{2}} \beta_{\mathrm{y}}\left(\begin{array}{c}
\sin \beta_{\mathrm{x}} \mathrm{x}^{\prime} \\
\cos \beta_{\mathrm{x}} \mathrm{x}^{\prime}
\end{array}\right)\left[\begin{array}{c}
\cos \beta_{\mathrm{y}} \mathrm{y}^{\prime} \\
-\sin \beta_{\mathrm{y}} \mathrm{y}^{\prime}
\end{array}\right]\left\{\begin{array}{l}
\sin \beta_{\mathrm{z}} \mathrm{z}^{\prime} \\
\cos \beta_{\mathrm{z}} \mathrm{z}^{\prime}
\end{array}\right\} \\
\mathrm{e}_{\mathrm{y}^{\prime}}=\frac{\mathrm{h}_{1} i \omega \mu_{0}}{\mathrm{k}_{1}^{2}-\beta_{\mathrm{z}}^{2}} \beta_{\mathrm{x}}\left(\begin{array}{c}
\cos \beta_{\mathrm{x}} \mathrm{x}^{\prime} \\
-\sin \beta_{\mathrm{x}} \mathrm{x}^{\prime}
\end{array}\right)\left[\begin{array}{c}
\sin \beta_{\mathrm{y}} \mathrm{y}^{\prime} \\
\cos \beta_{\mathrm{y}} \mathrm{y}^{\prime}
\end{array}\right]\left\{\begin{array}{c}
\sin \beta_{\mathrm{z}} \mathrm{z}^{\prime} \\
\cos \beta_{\mathrm{z}} \mathrm{z}^{\prime}
\end{array}\right\} \\
\mathrm{e}_{\mathrm{z}^{\prime}}=0 \\
\mathrm{~h}_{\mathrm{x}^{\prime}}=\frac{\mathrm{h}_{1}}{\mathrm{k}_{1}^{2}-\beta_{\mathrm{z}}^{2}} \beta_{\mathrm{x}} \beta_{\mathrm{z}}\left(\begin{array}{c}
\cos \beta_{\mathrm{x}} \mathrm{x}^{\prime} \\
-\sin \beta_{\mathrm{x}} \mathrm{x}^{\prime}
\end{array}\right)\left[\begin{array}{c}
\sin \beta_{\mathrm{y}} \mathrm{y}^{\prime} \\
\cos \beta_{\mathrm{y}} \mathrm{y}^{\prime}
\end{array}\right]\left\{\begin{array}{c}
\cos \beta_{\mathrm{z}} \mathrm{z}^{\prime} \\
-\sin \beta_{\mathrm{z}} \mathrm{z}^{\prime}
\end{array}\right\} \\
\mathrm{h}_{\mathrm{y}^{\prime}}=\frac{\mathrm{h}_{1}}{\mathrm{k}_{1}^{2}-\beta_{\mathrm{z}}^{2}} \beta_{\mathrm{y}} \beta_{\mathrm{z}}\left(\begin{array}{c}
\sin \beta_{\mathrm{x}} \mathrm{x}^{\prime} \\
\cos \beta_{\mathrm{x}} \mathrm{x}^{\prime}
\end{array}\right)\left[\begin{array}{c}
\cos \beta_{\mathrm{y}} \mathrm{y}^{\prime} \\
-\sin \beta_{\mathrm{y}} \mathrm{y}^{\prime}
\end{array}\right]\left\{\begin{array}{c}
\cos \beta_{\mathrm{z}} \mathrm{z}^{\prime} \\
-\sin \beta_{\mathrm{z}} \mathrm{z}^{\prime}
\end{array}\right\}
\end{gathered}
$$




$$
\mathrm{h}_{\mathrm{z}^{\prime}}=\mathrm{h}_{1}\left(\begin{array}{c}
\sin \beta_{\mathrm{x}} \mathrm{x}^{\prime} \\
\cos \beta_{\mathrm{x}} \mathrm{x}^{\prime}
\end{array}\right)\left[\begin{array}{l}
\sin \beta_{\mathrm{y}} \mathrm{y}^{\prime} \\
\cos \beta_{\mathrm{y}} \mathrm{y}^{\prime}
\end{array}\right]\left(\begin{array}{l}
\sin \beta_{\mathrm{z}} \mathrm{z}^{\prime} \\
\cos \beta_{\mathrm{z}} \mathrm{z}^{\prime}
\end{array}\right)
$$

Where $\left(\beta_{x}, \beta_{y}, \beta_{z}\right)$ - are the wave numbers; $\mathrm{k}_{0}=\omega \sqrt{\mu_{0} \varepsilon_{0}}, \mathrm{k}_{1}=\omega \sqrt{\mu_{0} \varepsilon_{1}} ; \mathrm{h}_{1}$ - is the amplitude; $\omega$ - is the circular frequency; $\mu_{0}$ - is the magnetic permeability; $\varepsilon_{0} ; \varepsilon_{1}$ - is the dielectric permittivity of the external space and resonator, respectively.

To obtain formulas for the coupling coefficients, we need to calculate the integral

$$
\mathrm{c}^{ \pm}=-1 / 2 \int_{\mathrm{S}}\left\{[\overrightarrow{\mathrm{e}}, \overrightarrow{\mathrm{n}}]\left(\overrightarrow{\mathrm{H}}^{ \pm}\right)^{*}+[\overrightarrow{\mathrm{n}}, \overrightarrow{\mathrm{h}}]\left(\overrightarrow{\mathrm{E}}^{ \pm}\right)^{*}\right\} \mathrm{ds}
$$

over the resonator surface $\mathrm{S}$. Here $\left(\overrightarrow{\mathrm{E}}^{ \pm}, \overrightarrow{\mathrm{H}}^{ \pm}\right)$- electric and magnetic fields of the eigenwaves of a rectangular waveguide, respectively.

For a rectangular resonator, it is more convenient to use an approximate representation (2) that is performed with an accuracy $1 / \mathrm{Q}_{\Sigma}$ :

$$
\mathrm{c}^{ \pm} \approx \mathrm{i} / 2 \omega\left(\varepsilon_{1}-\varepsilon_{0}\right) \int_{\mathrm{V}}\left(\overrightarrow{\mathrm{e}},\left(\overrightarrow{\mathrm{E}}^{ \pm}\right)^{*}\right) \mathrm{dv} .
$$

Where $\mathrm{Q}_{\Sigma}$ is the Q-factor of $\mathrm{DR}$ radiation; $\mathrm{V}$ - resonator volume.

The problem is that the resonator field and the waveguide field have a simple form in different coordinate systems. Therefore, to calculate (3), we represent the waveguide field [7] in the coordinate system of the dielectric resonator $\left(\mathrm{x}^{\prime}, \mathrm{y}^{\prime}, \mathrm{z}^{\prime}\right)$.

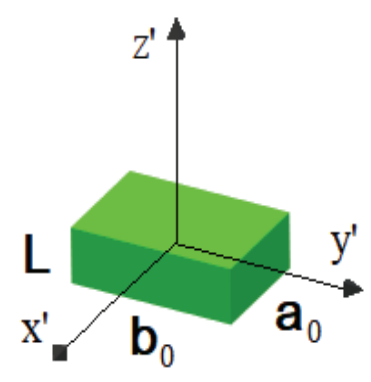

a

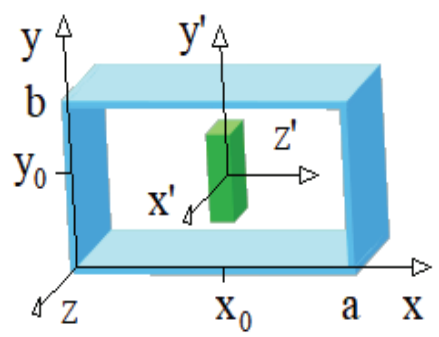

b

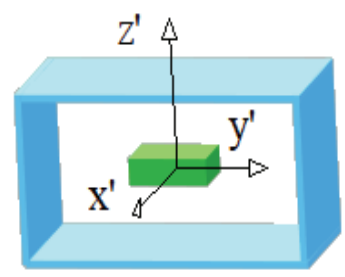

C

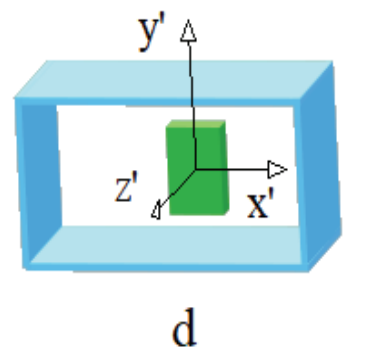

Fig. 1. Rectangular dielectric resonator in the local coordinate system (a). Standard positions of rectangular dielectric resonators in a waveguide $(b, c, d)$.

After calculating (3), the coupling coefficient of the resonator with the waveguide is represented according to the normalization of the waveguide field:

$$
\tilde{\mathrm{k}}_{\mathrm{S}}=\left|\mathrm{c}^{ \pm}\right|^{2} / \omega \mathrm{W}
$$


where $\mathrm{W}$ - energy stored in the dielectric of the resonator.

\section{Rotation of the dielectric resonator relative to the} $\mathbf{x}$-axis.

The description of the resonator rotation in the general case leads to rather cumbersome expressions, therefore, for simplicity, let us single out several simple cases of rotation about the fixed axes of the waveguide coordinate system $(\mathrm{x}, \mathrm{y}, \mathrm{z})$.

Let us first consider the rotation of a rectangular resonator relative to the $\mathrm{x}$-axis of the waveguide (Fig.2, a) for initial position shown on Fig. 1, d. In this case, the coupling coefficient of the DR with the $H_{10}$ wave of a rectangular waveguide has the form:

$$
\begin{aligned}
\tilde{\mathrm{k}}_{\mathrm{S}}=\tilde{\mathrm{k}}_{0} \cdot \beta_{\mathrm{x}}^{2} \cdot \cos ^{2} \beta_{2}\left|\varpi_{\mathrm{x}}\left(\chi_{1 \mathrm{x}} / \mathrm{k}_{0}\right) \omega_{\mathrm{y}}\left(\Gamma / \mathrm{k}_{0} \sin \beta_{2}\right) \omega_{\mathrm{z}}\left(\Gamma / \mathrm{k}_{0} \cos \beta_{2}\right)\right|^{2} \\
\cdot\left(\begin{array}{l}
\sin ^{2} \chi_{1 \mathrm{x}} \mathrm{x}_{0} \\
\cos ^{2} \chi_{1 \mathrm{x}} \mathrm{X}_{0}
\end{array}\right) .
\end{aligned}
$$

Where

$$
\begin{gathered}
\tilde{\mathrm{k}}_{0}=2 \cdot\left(\varepsilon_{\mathrm{lr}}-1\right)^{2} \cdot \frac{\mathrm{k}_{0}^{4}}{|\Gamma| \mathrm{ab}}\left(\beta_{\mathrm{x}} \beta_{\mathrm{y}} \beta_{\mathrm{z}}\right) \cdot \frac{\left(\mathrm{a}_{0} \mathrm{~b}_{0} \mathrm{~L}\right)^{2}}{\mathrm{vH}} \\
\mathrm{vH}=\varepsilon_{1 \mathrm{r}} \mathrm{k}_{0}^{2}\left[\beta_{\mathrm{y}}^{2} \pi_{\mathrm{x}}^{\mp} \pi_{\mathrm{y}}^{ \pm} \pi_{\mathrm{z}}^{\mp}+\beta_{\mathrm{x}}^{2} \pi_{\mathrm{x}}^{ \pm} \pi_{\mathrm{y}}^{\mp} \pi_{\mathrm{z}}^{\mp}\right]+ \\
+\beta_{\mathrm{x}}^{2} \beta_{\mathrm{z}}^{2} \cdot \pi_{\mathrm{x}}^{ \pm} \pi_{\mathrm{y}}^{\mp} \pi_{\mathrm{z}}^{ \pm}+\beta_{\mathrm{y}}^{2} \beta_{\mathrm{z}}^{2} \cdot \pi_{\mathrm{x}}^{\mp} \pi_{\mathrm{y}}^{ \pm} \pi_{\mathrm{z}}^{ \pm}+ \\
+\left(\beta_{\mathrm{x}}^{2}+\beta_{\mathrm{y}}^{2}\right)^{2} \cdot \pi_{\mathrm{x}}^{\mp} \pi_{\mathrm{y}}^{\mp} \pi_{\mathrm{z}}^{\mp}
\end{gathered}
$$

$\pi_{v}^{ \pm}=p_{v} \pm \sin p_{v} \cos p_{v} ; \quad v=(x, y, z)$.The upper and lower signs of $\pi_{v}^{ \pm}$correspond to the distributions of the DR field shown in brackets (1). $\varepsilon_{1 \mathrm{r}}=\varepsilon_{1} / \varepsilon_{0}$; $p_{x}=\beta_{x} a_{0} / 2 ; p_{y}=\beta_{y} b_{0} / 2 ; p_{z}=\beta_{z} L / 2$ - is the resonator characteristic parameters; $\chi_{1 x}=\pi / a$; $\left(x_{0}, y_{0}, z_{0}\right)$ is the coordinates of the center of the resonator in the waveguide; $\Gamma=\sqrt{k_{0}^{2}-\left(\chi_{1 x}\right)^{2}}$ the wave numbers of a rectangular waveguide with a cross section $a \times b$ for the fundamental wave of a magnetic type $H_{10}$ (Fig. 1, b) [7].

Here and below $\omega_{\mathrm{v}}(\xi)=\frac{1}{\mathrm{p}_{\mathrm{v}}^{2}-\left(\mathrm{q}_{\mathrm{v}} \xi\right)^{2}}$.

$\cdot\left(\begin{array}{c}-\mathrm{i}\left[\mathrm{p}_{\mathrm{v}} \cos \mathrm{p}_{\mathrm{v}} \sin \left(\mathrm{q}_{\mathrm{v}} \xi\right)-\mathrm{q}_{\mathrm{v}} \xi \sin \mathrm{p}_{\mathrm{v}} \cos \left(\mathrm{q}_{\mathrm{v}} \xi\right)\right] \\ \mathrm{p}_{\mathrm{v}} \sin \mathrm{p}_{\mathrm{v}} \cos \left(\mathrm{q}_{\mathrm{v}} \xi\right)-\mathrm{q}_{\mathrm{v}} \xi \cos \mathrm{p}_{\mathrm{v}} \sin \left(\mathrm{q}_{\mathrm{v}} \xi\right)\end{array}\right)$

$\varpi_{\mathrm{v}}(\xi)=\frac{1}{\mathrm{p}_{\mathrm{v}}^{2}-\left(\mathrm{q}_{\mathrm{v}} \xi\right)^{2}}$.

$\cdot\left(\begin{array}{c}\mathrm{p}_{\mathrm{v}} \sin \mathrm{p}_{\mathrm{v}} \cos \left(\mathrm{q}_{\mathrm{v}} \xi\right)-\mathrm{q}_{\mathrm{v}} \xi \cos \mathrm{p}_{\mathrm{v}} \sin \left(\mathrm{q}_{\mathrm{v}} \xi\right) \\ \mathrm{i}\left[\mathrm{p}_{\mathrm{v}} \cos \mathrm{p}_{\mathrm{v}} \sin \left(\mathrm{q}_{\mathrm{v}} \xi\right)-\mathrm{q}_{\mathrm{v}} \xi \sin \mathrm{p}_{\mathrm{v}} \cos \left(\mathrm{q}_{\mathrm{v}} \xi\right)\right]\end{array}\right) ;$

$v=(x, y, z) ; \quad q_{x}=k_{0} a_{0} / 2 ; \quad q_{y}=k_{0} b_{0} / 2$;

$q_{z}=k_{0} L / 2$.

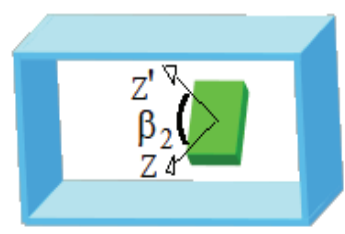

a

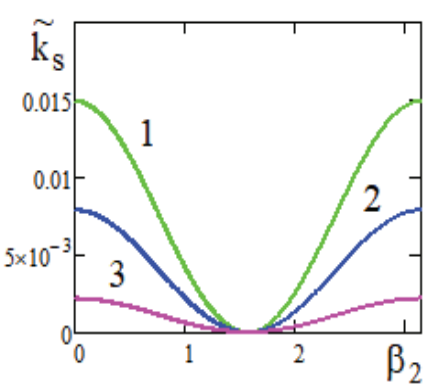

b

Fig.2. Rotation relatively the $\mathrm{x}$-axis of the dielectric resonator (a). Dependence of the DR coupling coefficient on the rotation angle $\beta_{2}$ (b): (1- $x_{0}=0,2 a ; 2-x_{0}=0,3 a ; 3$ $\left.x_{0}=0,4 a\right)$.

\section{Rotation of the dielectric resonator relative to the} y-axis.

The coupling coefficient of a dielectric resonator rotated relative to the y-axis with the $H_{10}$ wave of a rectangular waveguide at the initial position shown in Fig. 1, d, has the form:

$$
\begin{aligned}
& \tilde{\mathrm{k}}_{\mathrm{S}}=\tilde{\mathrm{k}}_{0} \cdot \frac{\beta_{\mathrm{x}}^{2}}{4} \cdot\left|\omega_{\mathrm{y}}(0)\right|^{2} \cdot \mid \mathrm{e}^{-\mathrm{i} \mathrm{\chi}_{1 \mathrm{x}} \mathrm{x}_{0}} \varpi_{\mathrm{x}}\left(-\left(\chi_{1 \mathrm{x}} / \mathrm{k}_{0} \cos \alpha_{1}+\Gamma / \mathrm{k}_{0} \sin \alpha_{1}\right)\right) \cdot \\
& \cdot \omega_{\mathrm{z}}\left(-\left(\chi_{1 \mathrm{x}} / \mathrm{k}_{0} \sin \alpha_{1}-\Gamma / \mathrm{k}_{0} \cos \alpha_{1}\right)\right)-
\end{aligned}
$$




$$
\begin{aligned}
& -\mathrm{e}^{\mathrm{i} \chi_{1 \mathrm{x}} \mathrm{x}_{0}} \bar{\varpi}_{\mathrm{x}}\left(\chi_{1 \mathrm{x}} / \mathrm{k}_{0} \cos \alpha_{1}-\Gamma / \mathrm{k}_{0} \sin \alpha_{1}\right) \cdot \\
& \left.\cdot \omega_{\mathrm{z}}\left(\chi_{1 \mathrm{x}} / \mathrm{k}_{0} \sin \alpha_{1}+\Gamma / \mathrm{k}_{0} \cos \alpha_{1}\right)\right|^{2} .
\end{aligned}
$$

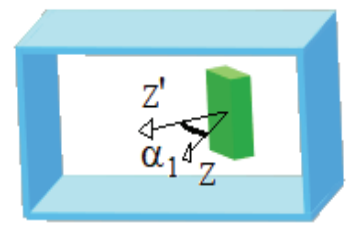

a

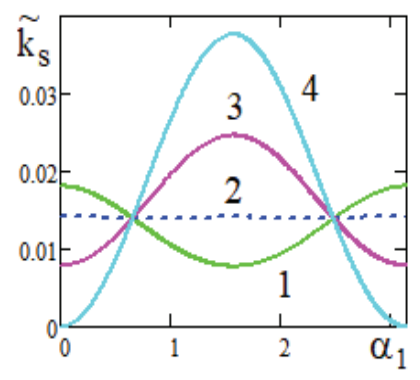

$\mathrm{b}$

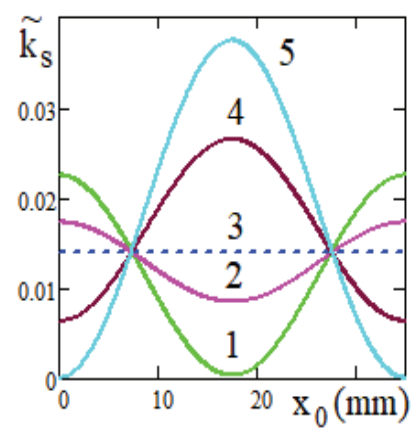

C

Fig. 3. Rotation relative to the y-axis of the dielectric resonator (a). Dependence of the DR coupling coefficient on the rotation angle $\alpha_{1}$ (b): (1- $x_{0}=0,15 a ; 2-x_{0}=7,341 \mathrm{~mm} ; 3$ $\left.x_{0}=0,3 a ; 4-x_{0}=0,5 a\right)$. Dependence of the coupling coefficient on the DR coordinate $x_{0}$ (c): $\left(1-\alpha_{1}=0,1 ; 2-\alpha_{1}=0,5\right.$; $\left.3-\alpha_{1}=0,659 ; 4-\alpha_{1}=1 ; 5-\alpha_{1}=1,5\right)$.

\section{Rotations of the dielectric resonator relative to the} z-axis.

In the case of rotation of the dielectric resonator relative to $\mathrm{z}$-axis at the initial position shown in Fig. $1, \mathrm{~d}$, the coupling coefficient takes the form:

$$
\begin{aligned}
& \tilde{\mathrm{k}}_{\mathrm{S}}=\tilde{\mathrm{k}}_{0} \cdot \mid \beta_{\mathrm{y}} \sin \alpha_{1} \omega_{\mathrm{x}}\left(\chi_{1 \mathrm{x}} / \mathrm{k}_{0} \cos \alpha_{1}\right) \omega_{\mathrm{y}}\left(\chi_{1 \mathrm{x}} / \mathrm{k}_{0} \sin \alpha_{1}\right)+ \\
& +\left.\beta_{\mathrm{x}} \cos \alpha_{1} \varpi_{\mathrm{x}}\left(\chi_{1 \mathrm{x}} / \mathrm{k}_{0} \cos \alpha_{1}\right) \omega_{\mathrm{y}}\left(\chi_{1 \mathrm{x}} / \mathrm{k}_{0} \sin \alpha_{1}\right)\right|^{2} \\
& \cdot\left|\omega_{\mathrm{y}}\left(\Gamma / \mathrm{k}_{0}\right)\right|^{2} \cos ^{2} \chi_{1 \mathrm{x}} \mathrm{x}_{0} \cdot
\end{aligned}
$$

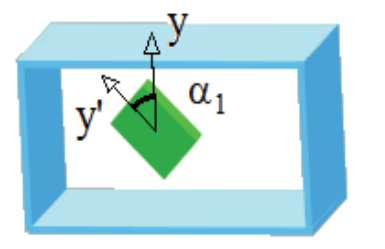

a

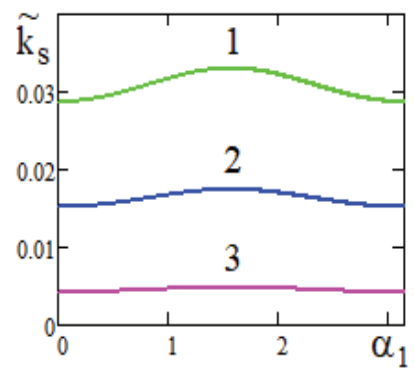

$\mathrm{b}$

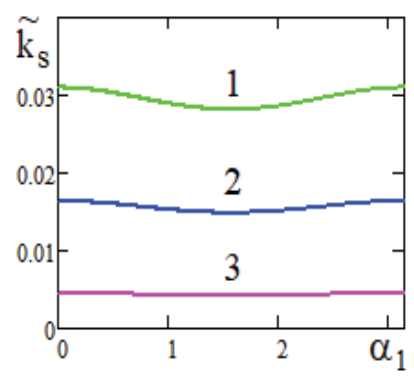

c

Fig.4. The dependence of the coupling coefficient of the DR on the angle of rotation for the initial position shown in Fig. 1, d. Dependence of the DR coupling coefficient on the rotation angle $\alpha_{1}:\left(1-x_{0}=0,2 a ; 2-x_{0}=0,3 a ; 3-x_{0}=0,4 a\right)$ for

$$
\mathrm{b}_{0} / \mathrm{a}_{0}=0,2(\mathrm{~b}) ; \mathrm{b}_{0} / \mathrm{a}_{0}=3 \text { (c). }
$$

In the case of rotation of the dielectric resonator around z-axis at the initial position shown in Fig. 1, b:

$\tilde{\mathrm{k}}_{\mathrm{S}}=\tilde{\mathrm{k}}_{0} \cdot\left|\beta_{\mathrm{x}} \cos \alpha_{1} \varpi_{\mathrm{x}}\left(\Gamma / \mathrm{k}_{0}\right) \omega_{\mathrm{y}}\left(\chi_{1 \mathrm{x}} / \mathrm{k}_{0} \sin \alpha_{1}\right) \omega_{\mathrm{z}}\left(\chi_{1 \mathrm{x}} / \mathrm{k}_{0} \cos \alpha_{1}\right)\right|^{2}$.

$\cdot \sin ^{2} \chi_{1 x} x_{0} \cdot$ 


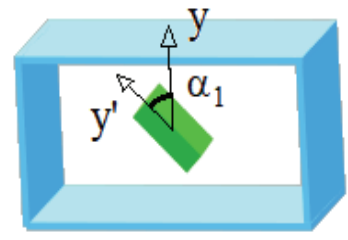

a
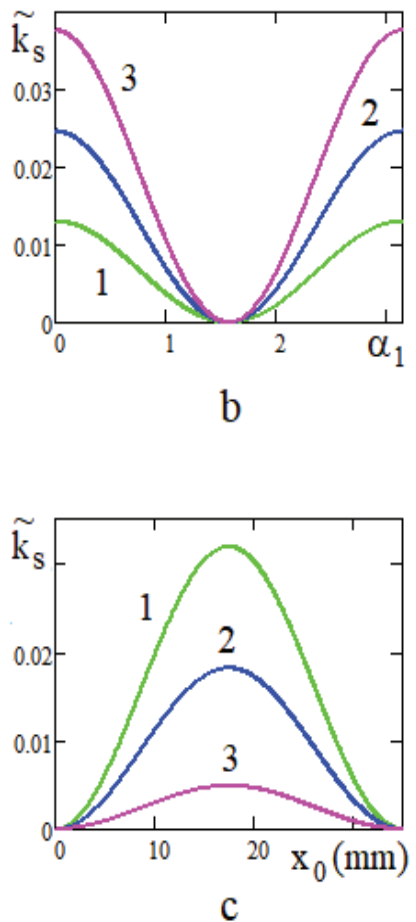

Fig. 5. The dependence of the coupling coefficient of the DR on the angle of rotation for the initial position shown in Fig. 1, b. Dependence of the coupling coefficient on the rotation angle $\alpha_{1}$ (b): $\left(1-x_{0}=0,2 a ; 2-x_{0}=0,3 a ; 3-x_{0}=0,5 a\right)$. Dependence of the coupling coefficient on the DR coordinate $x_{0}$ (c): $\left(1-\alpha_{1}=0,4 ; 2-\alpha_{1}=0,8 ; 3-\alpha_{1}=1,2\right)$.

\section{Calculation and analysis of coupling coeffi- cients}

Relations (4-7) were used for calculations the coupling coefficient dependences.

In Fig. 2-3, 5 depending on the coupling coefficients on the angles of rotation and transverse coordinates are plotted for the resonator with $\varepsilon_{1 \mathrm{r}}=36 ; \mathrm{a}_{0}=\mathrm{b}_{0}$; $\mathrm{L} / \mathrm{a}_{0}=0,4$. The cross section of the waveguide was $\mathrm{a} \times \mathrm{b}=35 \times 15 \mathrm{~mm}$; frequency of the fundamental magnetic oscillation of the resonator $\mathrm{H}_{111}$ $\left(h_{z}=h_{1} \cos \beta_{x} x^{\prime} \cos \beta_{y} y^{\prime} \cos \beta_{z} z^{\prime}\right.$ in (1)) $f=7 \mathrm{GHz}$.

The most interesting dependences were obtained for the rotation of the DR relative to the y-axis (Fig. 3, b, c). In the first case (Fig. 3, b, curve 2), we see that the coupling coefficient does not depend on the orientation of the DR axis at the point of "circular polarization" of the magnetic field of the waveguide:

$$
\mathrm{x}_{\mathrm{O}}=\frac{1}{\chi_{1 \mathrm{x}}} \operatorname{arcctg} \frac{|\Gamma|}{\chi_{1 \mathrm{x}}} .
$$

In the second case (Fig. 3, c), the coupling coefficient does not depend on the transverse coordinates when the axis of the DR is rotated by an angle:

$$
\mathrm{x}_{\mathrm{C}}=\operatorname{arcctg} \frac{|\Gamma|}{\chi_{1 \mathrm{x}}} .
$$

In other cases, the dependences of the coupling coefficients on the angles of rotation change according to nonharmonic laws. In limiting cases $\alpha_{1}, \beta_{2}=0, \pm \pi / 2$, expressions (4-7) coincide with the coupling coefficients for standard positions (Fig. 1, b-d) of the resonator in the waveguide.

\section{Discussion and Conclusion}

In the presented work, new analytical expressions are obtained for the coupling coefficients of rectangular DRs with a regular rectangular waveguide, when the DR is rotated relative to the waveguide axis.

In the case of rotation about an axis located parallel to the narrow wall of the waveguide, the coupling coefficients do not depend on the angles at the point of circular polarization of the magnetic field, and in the case of rotation of the DR by an angle determined only by the longitudinal and transverse wave numbers, they do not depend on coordinates.

In all cases, the dependences of the coupling coefficients on the angles of rotation change according to nonharmonic laws.

\section{References}

1. Tomassoni C., Bastioli S., Snyder R.V. Propagating Waveguide Filters Using Dielectric Resonators // IEEE Trans. on Microwave Theory and Techniques. 2015. Vol. 63, No. 12, pp. 4366-4375. 
2. Cameron R., Mansour R., Kudsia C., Microwave Filters for Communication Systems Fundamentals, Design and Applications. Wiley, New York, 2007, 804 p.

3. Dielectric Resonators. Edited by M.E. Ilchenko. M. Radio i sviaz. 1989, 327 p.

4. Trubin A.A., Kupriianov A.S., Fesenko V.I., Tuz V.R. Coupling coefficients for dielectric cuboids located in free space // Applied Optics. OSA, 2020 / Vol. 59, No 23/10. pp. $6918-6924$
5. Pidgurska T.V. Trubin A.A. Dual-bandpass filter built on rectangular dielectric resonators // Radioelectronics and Communications Systems / 2015. Vol. 58. pp.174-180.

6. Pidgurska T.V. Trubin A.A. Novel dual-band rectangular dielectric resonator filter // X International Symposium on Telecommunications - BIHTEL 2014, Sarajevo, Bosnia and Herzegovina. 2014. pp. 27-29.

7. Nikolskiy V.V. Electrodynamics and radio wave propagation. M. Nauka.1973. 607 p.

\section{Трубін 0.0. \\ Коефіцієнти зв'язку прямокутних діелектричних резонаторів з прямокутнім хвилеводом при обертанні їх осей}

Проблематика. Подальше підвищення швидкості передачі інформації визначається більш жорсткими вимогами, що пред'являються до елементів приймально-передавальних пристроїв. Одної із важливих складових частин таких пристроїв $€$ різноманітні фільтри, які часто виконуються на діелектричних резонаторах. Розрахунок параметрів багатоланкових фільтрів неможливо без подальшого розвитку теорії їх проектування. Розвиток теорії фільтрів базується на електродинамічному моделюванні яке передбачає розрахунок коефіцієнтів зв'язку діелектричних резонаторів в різноманітних лініях передачі.

Мета досліджень. Метою досліджень є розрахунки та дослідження коефіцієнтів зв'язку прямокутних діелектричних резонаторів $з$ прямокутним металевим хвилеводом при застосуванні нових структур з обертанням осей резонаторів. Дослідження нових ефектів, що дозволяють покращувати характеристики розсіювання фільтрів та інших пристрів на їх основі.

Методика реалізації. Для розрахунку та аналізу коефіцієнтів зв'язку використовуються методи технічної електродинаміки. Кінцевим результатом $є$ отримання нових аналітичних формул для нових структур з прямокутними діелектричними резонаторами, що дозволяють аналізувати і розраховувати їх коефіцієнти зв'язку.

Результати досліджень. Знайдено нові аналітичні вирази для коефіцієнтів зв'язку діелектричних резонаторів 3 обертанням їх осей в прямокутному хвилеводі.

Висновки. Розширено теорія конструювання фільтрів на нових структурах діелектричних резонаторів 3 обертанням їх осей в металевих хвилеводах. Знайдено нові аналітичні співвідношення та нові закономірності зміни коефіцієнтів зв'язку.

Ключові слова: діелектричний фільтр; прямокутний діелектричний резонатор; обертання; коефіцієнти зв'язку.

\section{Трубин А. $A$.}

Коэффициенты связи прямоугольных диэлектрических резонаторов с прямоугольным волноводом при вращении их осей

Проблематика. Дальнейшее повышение скорости передачи информации определяется более жесткими требованиями, предъявляемыми к элементам приемо-передающих устройств. Одной из важнейших составных частей таких устройств являются различные фильтры, которые часто выполняются на диэлектрических резонаторах. Расчет параметров многозвенных фильтров невозможен без дальнейшего развития теории их проектирования. Развитие теории фильтров базируется на электродинамическом моделировании, которое предполагает расчет коэффициентов связи диэлектрических резонаторов в различных линиях передачи.

Цель исследований. Целью исследований является расчет и исследование коэффициентов связи прямоугольных диэлектрических резонаторов с прямоугольным металлическим волноводом при вращении их осей. Исследование новых эффектов, позволяющих улучшать характеристики фильтров и других устройств на их основе.

Методика реализации. Для проведения расчета и анализа коэффициентов связи используются методы технической электродинамики. Конечным результатом является получение новых аналитических формул для новых структур с прямоугольными диэлектрическими резонаторами, которые позволяют анализировать и рассчитывать их коэффициенты связи.

Результаты исследований. Найдены новые аналитические выражения для коэффициентов связи диэлектрических резонаторов с вращением их осей в прямоугольном волноводе. 

WAVEGUIDE

Выводы. Расширена теория конструирования фильтров на новых структурах диэлектрических резонаторов с вращением их осей в металлических волноводах. Найдены новые аналитические соотношения и новые закономерности изменения коэффициентов связи.

Ключевые слова: диэлектрический фильтр; прямоугольный диэлектрический резонатор; вращение; коэффициенты связи. 